\title{
Tindak tutur ilokusi novel Surga Yang Tidak Dirindukan karya Asma Nadia (kajian pragmatik)
}

\author{
Nia Binti Qurota A'yuni ${ }^{1}$, Parji ${ }^{2}$ \\ 1,2) Universitas PGRI Madiun, Jl. Setiabudi No. 85 Madiun \\ e-mail: ${ }^{1}$ nianio30@gmail.com; ${ }^{2)}$ parji@unipma
}

\begin{abstract}
Abstrak
Penelitian ini bertujuan untuk mengetahui bentuktindak tutur ilokusi dalam novel Surga yang Tak Dirindukan Karya Asma Nadia dengan kajian Pragmatik. Metode penelitian yang digunakan adalah metode deskriptif kualitatif. Teknik pengumpulan data yang digunakan adalah dokumentasi dengan menggunakan novel Surga yang Tak Dirindukan karya Asma Nadia sebagai sumber data. Teknik analisis data yang digunakan adalah simak catat, yaitu dengan menganalisis bentuk tindak tutur ilokusiyang ada dalam novel Surga yang Tak Dirindukan Karya Asma Nadia.Hasil penelitian menunjukkan bentuk tindak tutur ilokusi dalam novel Surga yang Tak Dirindukanmeliputi: (a) bentuk ekspresif terdiri dari meminta maaf (7 data), memuji (4 data), dan menyalahkan (1 data); (b) bentuk asertif mencakup memberitakan (33 data), menyatakan (56 data), menyarankan (21 data), dan mengeluh (6 data);(c) bentuk direktif terdiri dari memerintah ( 3 data), menyuruh ( 6 data), menganjurkan (2 data), meminta (7 data), memohon (4 data), dan menasehati (12 data); serta (c) bentuk komisif mencakup menawarkan ( 7 data), menolak (17 data), dan berjanji (3 data).
\end{abstract}

Kata kunci: novel, tindak tutur, ilokusi, pragmatik

\section{Illocutionary of speech acts in the novel of "Surga Yang Tak Dirindukan" by Asma Nadia (a pragmatic ptudy)}

\begin{abstract}
This study aims to analyze the form of illocutionary of speech acts in Asma Nadia's novel Surga Yang Tak Dirindukan by using pragmatics study. This study used descriptive qualitative method. Data collection techniques used was documentation with Asma Nadia's novel Surga Yang Tak Dirindukanas source of data. The data analysis technique used was content analysis by analyzing the form of illocutionary speech acts in Asma Nadia's novel Surga Yang Tak Dirindukan. The result indicates that Surga Yang Tak Dirindukan novel contains the forms of speech acts illocutionary as follows: (a) expressive form consists of appologizing (7 data), praising (4 data), and deploring (1 data); (b) assertive form consists of telling (33 data), stating (56 data), suggesing ( 21 data), and complaining ( 6 data); (c) directive form consists of ordering (3 data), commanding (6 data), advocating (2 data), requesting (7 data), begging (4 data), and advising (12 Data ); and (d)commissive form consists of offering (7 data), refusing (17 data), and promising (3 data)).
\end{abstract}

Keywords: novel, speech act, illocutionary, pragmatics words here

\section{Pendahuluan}

Bahasa menjadi faktor penentu utama dalam berkomunikasi. Bahasa yang baik dapat menimbulkan respon yang baik dan timbal balik yang cepat. Apabila pengguna bahasa tidak menggunakan bahasa yang baik dan efisien maka respon lambat akan 
terjadi pada penerima pesan. Bahasa yang baik secara umum dapat menimbulkan respon cepat dan efisien bagi penerima dan pembicara.

Masyarakat pengguna bahasa khususnya menggunakan bahasa untuk interaksi sosial. Kegiatan interaksi antarmasyarakat menimbulkan beberapa komponen tutur yang harus ada dalam komunikasi khususnya tuturan. Komponen tuturan yang ada secara tidak langsung adalah pendengar yang menyampaikan pesan kepada pembicara secara langsung bertatap muka atau menggunakan media. Proses penyampaian pesan diharapkan mendapat timbal balik sesuai dengan konteks tuturannya.

Proses komunikasi yang terjadi dapat menimbulkan beberapa tindakan. Ketika pembicara menyampaikan pesan maka pembicara tersebut telah melakukan kegiatan berbicara. Pendengar pun mendengarkan pembicara menyampaikan pesan maka pendengar tersebut telah melakukan kegiatan menyimak pesan. Ketika komunikasi terjadi secara tidak langsung maka pendengar dan pembicara tersebut melakukan tindakan dan tuturan.

Yule (2006: 83) menyatakan bahwa pada suatu saat, tindakan yang ditampilkan dengan menghasilkan suatu tuturan akan membentuk tuturan dengan beberapa fungsi di dalam fikiran atau tindak ilokusi. Tuturan Ilokusi menjadi tuturan yang menentukan setiap maksud dari tuturan yang disampaikan oleh penutur kepada lawan tutur. Tindak ilokusi menghasilkan beberapa fungsi dalam setiap tuturan yang disampaikan.

Karya yang dihasilkan seorang penulis merupakan kreativitas dan hasil imajinasi penulis. Penggunaan bahasa yang kreatif dan bentuk tuturan yang ekspresif mampu menghasilkan karya yang menarik. Tidak berbeda dengan novel dimana penulis menggambarkan tokoh beserta alur cerita menggunakan imajinasi baik dari dunia nyata maupun fiksi.

Novel sebagai sebuah karya sastra yang ditulis oleh seorang penulis menggunakan bahasa sehari-hari. Karya sastra berupa novel merupakan lambang kesenian yang baru yang berdasarkan fakta dan pengalaman pengarangnya (Waluyo, 2002: 36). Susunan yang digambarkan novel adalah suatu yang realistis dan masuk akal.

Percakapan dalam novel merupakan wujud tuturan tertulis. Tuturan sendiri dapat dikaji menggunakan kajian pragmatik. Tarigan (2009: 30) menyatakan bahwa pragmatik adalah telaah mengenai hubungan antara bahasa dan konteks yang tergramatisasikan atau disandikan dalam struktur suatu bahasa.

Dalam penelitian ini, peneliti mengkaji tindak tutur ilokusi dalam sebuah novel yang berjudul Surga yang Tak Dirindukan karya Asma Nadia. Penggunaan bahasa percakapan yang ada dalam novel tersebut menarik untuk dikaji menggunakan kajian pragmatik. Khususnya kajian dalam tindak tutur ilokusi sehingga dapat menambah wawasan untuk pembaca.

Sumarsono (2010: 321) menyatakan bahwa tindak tutur merupakan perangkat terkecil dalam jenjang, yang merupakan derajat paling sederhana dan sekaligus paling sulit. Austin (dalam Sumarsono, 2010: 181) yang menyatakan bahwa mengucapkan sesuatu adalah melakukan sesuatu. Dan di situ ada tindak tutur. Bahasa dapat digunakan untuk "membuat kejadian".

Searle (dalam Nadar, 2013: 14) menyatakan bahwa Tindak ilokusioner adalah apa yang ingin dicapai oleh penuturnya pada waktu menuturkan sesuatu dan dapat merupakan tindakan menyatakan, berjanji, minta maaf, mengancam, meramalkan, memerintah, meminta, dan lain sebagainya. Austin (dalam Tarigan, 2009: 34) menyatakan bahwa Tindak ilokusi adalah melakukan suatu tindakan dalam mengatakan sesuatu.

Austin (dalam Sumarsono, 2010: 181) menyatakan bahwa secara analitis llokusi dari suatu ujaran ialah daya (force) yang ditimbulkan oleh pemakaiannya sebagai suatu perintah, ejekan, keluhan, pujian, dsb. Tindak ilokusi ialah tindak 
melakukan sesuatu, yang menjadi maksud, fungsi, atau daya dari ujaran. Searle (dalam Tarigan, 2009: 42) mengklasifikasikan tindak ilokusi berdasarkan berbagai kriteria yaitu Asertif, Direktif, Komisif, Ekspresif, Deklaratif.

Waluyo (2002: 36) menyatakan bahwa novel adalah lambang kesenian yang baru yang berdasarkan fakta dan pengalaman pengarangnya. Nurgiyantoro (2012: 9) menyatakan bahwa dewasa ini istilah novella dan novelle mengandung pengertian yang sama dengan istilah Indonesia novelet (Inggris: novellette), yang berarti sebuah karya prosa fiksi yang panjangnya cukupan, tidak terlalu panjang, namun juga tidak terlalu pendek.

Tarigan (2009: 30) menyatakan bahwa pragmatik adalah telaah mengenai hubungan antara bahasa dan konteks yang tergramatisasikan atau disandikan dalam struktur suatu bahasa.Levinson (dalam Tarigan, 2009: 31) menyatakan bahwa pragmatik adalah telaah mengenai relasi antara bahasa dan konteks yang merupakan dasar bagi suatu catatan atau laporan pemahaman bahasa, dengan kata lain telaah mengenai kemampuan pemakai bahasa menghubungkan serta penyerasian kalimatkalimat dan konteks-konteks secara tepat.

\section{Metode Penelitian}

Pendekatan yang digunakan dalam penelitian ini adalah pendekatan pragmatik yaitu menyelidiki bagaimana cara pendengar dapat menyimpulkan tentang apa yang dituturkan agar dapat sampai pada suatu interpretasi makna yang dimaksudkan oleh penutur. Jenis penelitian yang digunakan adalah penelitian deskriptif kualitatif. Sutopo (2002: 111) menyebutkan bahwa penelitian deskriptif kualitatif mengarah pada pendeskripsian secara rinci dan mendalam mengenai potret kondisi tentang apa yang sebenarnya terjadi menurut apa adanya di lapangan studinya.

Sugiyono (2014: 62) menyatakan bahwa dalam penelitian kualitatif terdapat sumber data primer yaitu sumber data yang langsung memberikan data kepada pengumpul data. Sumber data sekunder yaitu sumber yang tidak langsung memberikan data kepada pengumpul data, misalnya lewat orang lain atau lewat dokumen sumber data primer dalam penelitian ini adalah novel surga yang tak dirindukan karya asma nadia. Teknik pengumpulan data dalam penelitian ini berupa tinjauan pustaka.

Teknik analisis data yang digunakan dalam penelitian ini adalah analisis isi (content analysis). Bungin (2007: 155) menyatakan bahwa analisis isi (content analysis) adalah teknik penelitian untuk membuat inferensi-inferensi yang dapat ditiru (replicable), dan sahih data dengan memerhatikan konteksnya.

Usaha-usaha yang dapat ditempuh oleh peneliti untuk memperoleh keabsahan data penelitian adalah dengan meneliti kredibilitas temuan menggunakan teknik trianggulasi berupa ketekunan/keajegan pengamatan. Moleong (2010: 329) menyatakan bahwa keajegan pengamatan berarti mencari secara konsisten interpretasi dengan berbagai cara dalam kaitan dengan proses analisis yang konstan atau tentatif.

\section{Hasil dan Pembahasan}

Pada bagian ini, dijelaskan hasil penelitian dan pada saat yang sama diberikan pembahasan yang komprehensif. Hasil dapat disajikan dalam angka, grafik, tabel dan lain-lain yang membuat pembaca memahami dengan mudah [2], [5]. Pembahasan dapat dibuat dalam beberapa sub-bab sesuai kebutuhan.

Searle (dalam Tarigan, 2009: 42) menyatakan bahwa tuturan ekspresif mempunyai fungsi untuk mengekspresikan, mengungkapkan atau memberitahukan sikap psikologis sang pembicara menuju suatu pernyataan keadaan yang diperkirakan oleh ilokusi. 


\section{Ekspresif meminta maaf}

Tuturan ekspresif meminta maaf dimaksudkan penutur untuk menyampaikan maaf kepada lawan tutur. Penggambaran tuturan meminta maaf merupakan bentuk ekspresi penutur terhadap lawan tutur. Maksud dan tujuan dari tindak tutur ilokusi ekspresif meminta maaf adalah menyampaikan ungkapan permintaan maaf penutur terhadap lawan tutur.

\section{Ekspresif memuji}

Penggambaran tuturan ekpresif memuji adalah penutur memberikan pujian terhadap lawan tutur. Maksud dan tujuan dari penutur adalah mengapresiasi sesuatu yang dilakukan lawan tutur dalam bentuk kata-kata. Ekspresi pujian dengan kata-kata yang dilakukan penutur terhadap lawan tutur.

Ekspresif menyalahkan

Tuturan ekspresif menyalahkan merupakan bentuk ekspresi penutur terhadap lawan tutur berupa menyalahkan. Penutur menganggap lawan tutur melakukan kesalahan sehingga penutur memberikan ekspresi ucapan menyalahkan kepada lawan tutur.

Searle (dalam Tarigan, 2009: 42) menyatakan bahwa tuturan asertif melibatkan pembicara pada kebenaran proposisi yang diekspresikan, misalnya: menyatakan, memberitahukan, menyarankan, membanggakan, mengeluh, menuntut, melaporkan.

\section{Asertif memberitakan}

Tuturan asertif memberitakan merupakan bentuk tuturan yang dimaksudkan untuk mengabarkan sesuatu. Penutur bermaksud memberi petunjuk mengenai apa yang sedang terjadi secara langsung kepada lawan tutur. Bentuk tututan ilokusi asertif memberitakan ini merupakan pengabaran secara langsung kepada lawan tutur tentang kondisi yang sedang berlangsung.

\section{Asertif menyarankan}

Bentuk tuturan asertif menyarankan merupakan bentuk tuturan yang dimaksudkan memberikan masukan terhadap lawan tutur. Tuturan menyarankan tersebut dapat disampaikan menggunakan kalimat langsung maupun secara tidak langsung kepada lawan tutur. Tuturan tersebut dapat menggunakan kalimat perintah yang disampaikan secara eksplisit.

\section{Asertif menyatakan}

Bentuk tuturan asertif menyatakan merupakan bentuk tuturan yang digunakan untuk menyatakan sebuah pernyataan. Tanpa disadari setiap kalimat pernyataan merupakan tuturan yang menyatakan sesuatu. Ketika menyampaikan tuturan kepada lawan tutur yang dimaksudkan untuk memberikan kepastian tentang sebuah pernyataan yang disampaikan oleh lawan tutur.

\section{Asertif mengeluh}

Bentuk tuturan ilokusi mengeluh merupakan bentuk tuturan yang disampaikan penutur terhadap lawan tutur. Mengeluh merupakan wujud rasa tidak nyaman dengan sesuatu pernyataan yang didengar oleh lawan tutur. Tuturan mengeluh dapat berupa sanggahan maupun penolakan.

Searle (dalam Tarigan, 2009: 42) menyatakan bahwa tuturan komisif melibatkan pembicara pada beberapa tindakan yang akan datang, misalnya: menjanjikan, bersumpah, menawarkan, memanjatkan (doa).

Komisif menawarkan.

Bentuk tuturan komisif menawarkan merupakan bentuk tuturan yang bertujuan untuk memberikan penawaran terhadap sesuatu. Penutur bermaksud untuk memberikan beberapa pilihan sekaligus mengklarifikasi pilihan yang ditentukan oleh 
lawan tutur. Penutur menawarkan sesuai dengan pilihan yang ada secara langsung kepada lawan tutur.

Komisif menolak

Bentuk tuturan yang komisif menolak adalah bentuk tuturan yang digunakan oleh penutur untuk menolak secara tidak langsung. Penutur menyampaikan pernyataan penolakan berupa sanggahan ataupun pendapat yang disertai dengan alasan konkrit. Menolak secara tidak langsung tentang sebuah pernyataan yang didengar.

Komisif berjanji

Tuturan komisif berjanji adalah bentuk tuturan yang disampaikan penutur untuk menyataan kesediaan ataupun kesanggupan terhadap sesuatu. Penutur memberikan kesanggupan kepada lawan tutur untuk tidak mengganggu misalnya. Penutur sanggup untuk meninggalkan lawan tutur sebagai wujud janjinya.

Searle (dalam Tarigan, 2009: 42) menyatakan bahwa tuturan direktif dimaksudkan untuk menimbulkan beberapa efek melalui tindakan sang penyimak, misalnya: memesan, memerintahkan, memohon, meminta, menyarankan, menganjurkan, menasihatkan.

Direktif menganjurkan

Bentuk tuturan direktif menganjurkan adalah bentuk tuturan dimana penutur memberikan masukan terhadap sesuatu yang tidak sesuai. Pernyataan tuturan menganjurkan hampir sama dengan menyarankan. Pernyataan tersebut dapat secara langsung ataupun tidak langsung.

\section{Direktif menasehati}

Bentuk tuturan menasehati merupakan bentuk tuturan yang dimaksudkan untu memberikan nasihat, pesan atau masukan. Penutur memberikan nasihat terhadap lawan tutur tentang hal-hal yang kurang baik untuk dilakukan oleh lawan tutur. bentuk tuturan menasehati dapat berupa pernyataan ataupun pesan.

Direktif memerintah

Bentuk tuturan direktif memerintah merupakan bentuk tuturan perintah. Tuturan tersebut berupa kalimat perintah baik secara langsung ataupun tidak langsung. Tuturan memerintah disampaikan kepada lawan tutur yang dimaksudkan untuk melaksanakan suatu perintah.

Direktif menyuruh

Bentuk tuturan direktif menyuruh adalah bentuk tuturan ilokusi yang dimaksudkan untuk menyuruh atau hampir sama dengan memerintah. Pernyataan menyuruh diungkapkan menggunakan pernyataan tidak langsung dan disertai dengan sindiran secara tidak langsung. Tuturan menyuruh hampir memiliki kesamaan dengan memerintah namun berbeda dalam pengucapan dan nada bicara.

\section{Direktif memohon}

Bentuk tuturan memohon merupakan pernyataan permohonan yang disampaikan penutur terhadap lawan tutur. Penutur meminta terhadap lawan tutur secara halus untuk sesuatu yang diinginkan. Penutur menggunakan kalimat yang sopan untuk menyampaikan tuturan permohonan kepada lawan tutur.

\section{Direktif meminta}

Bentuk tuturan ilokusi direktif meminta merupakan bentuk tuturan yang disampaikan penutur untuk memperoleh sesuatu. Penutur menyampaikan permintaan untuk memperoleh sesuatu kepada lawan tutur. Penutur menginginkan sesuatu yang disampaikan kepada lawan tutur baik secara langsung ataupun tidak langsung dengan pernyataan. 
Penelitian yang dilakukan oleh peneliti menemukan data yang berbeda dalam novel yang berbeda. Peneliti menemukan bentuk ilokusi berupa bentuk ekspresif (meminta maaf, memuji dan menyalahkan), bentuk asertif (memberitakan, menyatakan, menyarankan, dan mengeluh), bentuk direktif (memerintah, menyuruh, menasehati, meminta, menganjurkan dan memohon), dan bentuk komisif (menawarkan, menolak dan berjanji).

Sedangkan Gamgulu (2015) menyatakan bahwa tindak ilokusi adalah tindak tutur yang biasanya diidentifikasikan dengan kalimat performatif yang eksplisit. Tindak tutur ilokusi biasanya berkenaan dengan pemberian janji, ucapan terima kasih, menyuruh, menawarkan dan menjanjikan

\section{Kesimpulan}

Berdasarkan hasil penelitian dan pembahasan dapat disimpulkan bahwa dalam bentuk tidak tutur ilokusi dalam novelSurga yang Tak Dirindukan karya Asma Nadia terdapat 5 fungsi yaitu ekspresif, asertif, direktif, dan komisif. Fungsi ekspresif berupa meminta maaf, memuji, dan menyalahkan. Fungsi asertif berupa memberitakan, menyatakan, menyarankan dan mengeluh. Fungsi direktif berupa memerintah, menyuruh, menganjurkan, meminta, memohon, dan menasehati. Fungsi komisif berupa menwarkan, menolak dan berjanji.

Semoga dengan adanya penelitian ini dapat bermanfaat bagi penelitian yang sama dalam bidang yang sama. Penelitian yang dilakukan oleh peneliti dapat dijadikan acuan untuk meningkatkan penulisan tuturan dalam novel khususnya oleh pengarang. Penelitian ini diharapkan dapat meningkatkan pengetahuan pembaca khususnya dalam kajian pragmatik dan tindak tutur.

\section{Daftar Pustaka}

Bungin, B. (2007). Penelitian Kualitatif: Komunikasi, Ekonomi, Kebijakan Publik, dan IImu Sosial Lainnya. Jakarta: Kencana Prenada Media Group.

Gamgulu, N. (2015). Analisis Tindak Tutur Dalam Novel Ayat-Ayat Cinta Karya Habiburrahman El Shirazy (Suatu Kajian Pragmatik). Skripsi. Manado: Fakultas Ilmu Budaya Universitas Sam Ratulangi.

Moleong, L. (2007). Metodologi Penelitian Kualitatif. Bandung: PT. Remaja Rosdakarya Offset.

Nadar, F.X. (2013). Pragmatik \& Penelitian Pragmatik. Yogyakarta: Graha Ilmu.

Nadia, A. (2014). Surga Yang Tak Dirindukan. Depok: Asma Nadia Publishing House.

Nurgiyantoro, Bu. (2012). Teori Pengkajian Fiksi. Yogyakarta: Gadjah Mada University Press.

Sumarsono. (2010). Pragmatik: buku ajar. Singaraja: Universitas Pendidikan Ganesha.

Sumarsono. (2010). Sosiolinguistik. Yogyakarta: SABDA.

Tarigan, H.G. (2009). Pengajaran Pragmatik. Bandung: Angkasa.

Yule, G. (2006). Pragmatik. Yogyakarta: Pustaka Pelajar. 